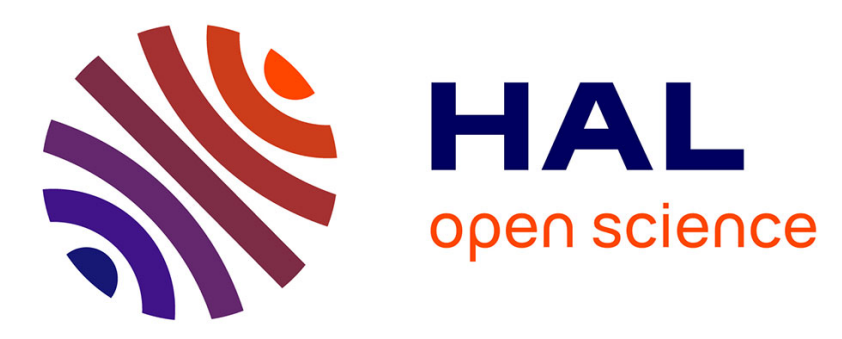

\title{
Neural network treatment of 4 years long NO measurement in temperate spruce and beech forests
}

Richard Dupont, Klaus Butterbach-Bahl, Claire Delon, Nicolas Brüggemann, Dominique Serça

\section{- To cite this version:}

Richard Dupont, Klaus Butterbach-Bahl, Claire Delon, Nicolas Brüggemann, Dominique Serça. Neural network treatment of 4 years long NO measurement in temperate spruce and beech forests. Journal of Geophysical Research: Biogeosciences, 2008, 113 (G4), pp.G04001. 10.1029/2007JG000665 . hal00519790

\section{HAL Id: hal-00519790 \\ https://hal.science/hal-00519790}

Submitted on 8 Feb 2022

HAL is a multi-disciplinary open access archive for the deposit and dissemination of scientific research documents, whether they are published or not. The documents may come from teaching and research institutions in France or abroad, or from public or private research centers.
L'archive ouverte pluridisciplinaire HAL, est destinée au dépôt et à la diffusion de documents scientifiques de niveau recherche, publiés ou non, émanant des établissements d'enseignement et de recherche français ou étrangers, des laboratoires publics ou privés. 


\title{
Neural network treatment of 4 years long NO measurement in temperate spruce and beech forests
}

\author{
R. Dupont, ${ }^{1}$ K. Butterbach-Bahl, ${ }^{2}$ C. Delon, ${ }^{1}$ N. Bruggemann, ${ }^{2}$ and D. Serça ${ }^{1}$ \\ Received 21 December 2007; revised 4 March 2008; accepted 20 March 2008; published 7 October 2008.
}

[1] NO soil emissions are directly influenced by soil environmental (temperature, humidity), chemical ( $\mathrm{pH}, \mathrm{N}$ content, $\mathrm{C}$ content. .) and physical (soil content, texture) variables. All these parameters exert linear or non linear influences that fluctuate in threshold and intensity between sites. Because of the lack of field experiments and to the high variability in time (diurnal and seasonal cycle) and space (regions, soil and vegetation type) of the environmental parameters influencing NO emissions, estimates of NO emissions worldwide still remain highly uncertain. In this study we developed nonlinear regressions to describe NO flux emission from soil in dependency with relevant environmental parameters for a forest site in a temperate region (Höglwald, South Germany, 1994-1997) using an Artificial Neural Network (ANN). The resulting algorithm links NO fluxes with air, surface and depth temperatures, surface WFPS (Water Field Pore Space) and humus $\mathrm{pH}$. All these parameters were evaluated and selected as relevant and non redundant. Network performances are evaluated for different numbers of hidden neurons. Resulting equations linking NO fluxes from soils and variables are obtained, and show to perform well with measurements $\left(\mathrm{R}^{2}=0.81\right)$. Average NO fluxes values of $14.6 \mathrm{gN} \mathrm{ha}^{-1 \mathrm{~d}-1}$ are obtained for calculated and measured fluxes. In a second part, 2002-2003 NO soil fluxes are estimated from the ANN equation obtained from 19941997 flux measurements performed at the same site. Overall, simulated results give a good estimation of NO fluxes, with a mean value of $15.3 \mathrm{gN} \mathrm{ha} \mathrm{d}^{-1}$ close to the $21.7 \mathrm{gN} \mathrm{ha} \mathrm{d}^{-1}$ measured mean for the 2002-2003 period. ANN algorithm gives also a good representation of low frequency (seasonal) variations. On the basis of our results, we suggest that ANN is a good alternative between detailed biogeochemical models and large scale models, and may be the appropriate tool for estimating $\mathrm{NO}$ emissions at a regional scale.

Citation: Dupont, R., K. Butterbach-Bahl, C. Delon, N. Bruggemann, and D. Serça (2008), Neural network treatment of 4 years long NO measurement in temperate spruce and beech forests, J. Geophys. Res., 113, G04001, doi:10.1029/2007JG000665.

\section{Introduction}

[2] In the context of global warming and atmospheric oxidizing capacity changes, identifying and quantifying air pollutant sources are major issues in atmospheric and climatic sciences. Indeed, $\mathrm{NOx}$ (here $\mathrm{NO}+\mathrm{NO}_{2}=\mathrm{NOx}$ ) take part in the ozone production-destruction cycle with Volatil Organic Compounds (VOCs) and solar radiation, affecting the budget of the hydroxyl radical $(\mathrm{OH})$, and in turn the tropospheric oxidizing efficiency. Nitrogen oxides are important gaseous species that have a major impact on atmospheric chemistry. Once emitted in the atmosphere, NO is immediately oxidized into $\mathrm{NO}_{2}$ by its reaction with $\mathrm{O}_{3}$. Consequently, changes in NO emissions lead to modifica-

\footnotetext{
${ }^{1}$ Laboratoire d'Aérologie, Centre National de Recherche Scientifique/ Université Paul Sabatier, Toulouse, France.

${ }^{2}$ Karlsruhe Research Center, Institute of Meteorology and Climate Research, Atmospheric Environmental Research, (IMK-IFU), GarmischPartenkirchen, Germany.

Copyright 2008 by the American Geophysical Union. 0148-0227/08/2007JG000665
}

tions in NOx concentrations, and in the rate of ozone production. Quantifying sources of NO emissions is therefore important to better understand atmospheric chemistry.

[3] NOx concentrations increase around $0.25 \%$ per year [Houghton, 1996], a rise linked to anthropogenic sources and changes in land use [Kroeze et al., 1999]. However, at the global scale, soil NO emissions are estimated to represent $40 \%$ of total (anthropogenic + biogenic) NO emissions [Williams et al., 1992], an amount comparable to fossil fuel combustions [Davidson and Kingerlee, 1997; Delmas et al., 1997]. NO is naturally produced and emitted from soils upon microbial processes referred to as nitrification and denitrification. The magnitudes of both processes are depending on soil properties, environmental conditions (temperature, soil moisture, oxygen), nitrogen and carbon availability [Gasche et al., 2002], and biological $\mathrm{N}_{2}$ fixation. Estimates for global soil $\mathrm{NO}$ emissions range from 4.7 $\mathrm{TgN} \cdot \mathrm{a}^{-1}$ [Müller, 1992] to $21 \mathrm{TgN} \cdot \mathrm{a}^{-1}$ [Davidson and Kingerlee, 1997] before canopy uptake (reduced to $13 \mathrm{TgN} \cdot \mathrm{a}^{-1}$ above canopy). Global estimates are based on a limited number of measurements at selected sites, which by far do not span the observed variability in, e.g., soil 
types, soil properties and environmental conditions. Therefore these inventories have a rather low precision.

[4] Soils NO emissions have been shown to be mainly influenced by several environmental factors such as soil temperature, water content, $\mathrm{pH}$ and $\mathrm{N}$ content. Because of its direct effect on microbial metabolism, one of the most important parameter is soil temperature, causing, e.g., diurnal patterns of NO fluxes. In temperate soils, increasing temperature involves an exponential increase of NO emissions [Williams et al., 1992; Martin et al., 1998]. NO production in soils is either due to the oxidative process of nitrification, i.e., the microbial mediated oxidation of $\mathrm{NH}_{3}$ to $\mathrm{NO}_{3}$ involving molecular $\mathrm{O}_{2}$, or due to the reductive process of denitrification, i.e., the reduction of $\mathrm{NO}_{3} / \mathrm{NO}_{2}$ to $\mathrm{N}_{2}$ in conditions of $\mathrm{O}_{2}$ limitation. A major controller of gas and $\mathrm{O}_{2}$ diffusion into the soil is soil moisture. High soil moisture content reduces the diffusion capacity of the soil matrix and favors the development of anaerobic zones, i.e., also favors denitrification processes. On the other hand, if soil moisture is below a certain threshold, nitrification stops as well as the NO production by nitrification.

[5] Seasonal variations in NO fluxes have often been found to be strongly linked to seasonal changes in soil moisture [Meixner and Yang, 2004], in particular in tropical soils. NO flux pulses following rewetting of tropical soils after the dry season have been described by Johansson et al. [1988] and Yienger and Levy [1995]. Pulse effects can be described as an increase of emissions up to a maximum after passing a certain threshold in WFPS (Water Filled Pore Space) [Meixner and Yang, 2004; Otter et al., 1999]. However, each type of soil has its specific WFPS level for optimum NO production [Roelle, 2001; Skopp et al., 1990].

[6] The $\mathrm{pH}$ of the soil matrix is considered to be an influent parameter onto soil NO emissions, due to its importance in regulating the magnitude of nitrification and denitrification [Davidson, 1991] and in controlling NO losses during both processes. For soil $\mathrm{pH}<4.0$, NO can even be produced by chemo-denitrification from nitrite [Van Cleemput and Baert, 1984; Kesik et al., 2006]. Process studies have linked soil $\mathrm{pH}$ and biogenic emissions, concluding that soil NO emissions are at optimum when the soil is either $<5$ or $>8$ [Ormeci et al., 1999; Serça et al., 1994; Kesik et al., 2006]. Furthermore, NO production in soils depends on the availability of mineral $\mathrm{N}$ for microbial nitrification and denitrification. The mineral $\mathrm{N}$ content in soils is controlled by the mineralization activity in a given soil, but is also subject of direct and indirect anthropogenic effects via fertilization (agricultural soils) or atmospheric $\mathrm{N}$ deposition. In summary, NO fluxes depend on climate, soil type, vegetation and applied fertilizer [Mc Taggart et al., 2002; Roelle et al., 1999]. Consequently, uncertainties in quantifying NO emissions from soils rely on the difficulty of taking into account all these influent parameters. As a matter of fact, the common goal of the different NO flux parameterization studies is to identify the most relevant parameters influencing NO biogeochemical processes and emissions from soil.

[7] The artificial neural network (ANN) methodology is applied in this study to find the best nonlinear regressions between a list of selected environmental parameters and NO emission fluxes. Even if it has been used in atmospheric sciences and pollutant concentrations prediction [Anghel and Ozunu, 2006], ANN is a real original approach to determine NO emissions from soils. This statistical method does not need a complex description of the environment, but as shown here, only a few relevant soil parameters. Another possibility for estimating soil NO emissions is the use of process oriented models [Li et al., 2000; Kesik et al., 2005]. These models simulate the major processes involved in $\mathrm{C}$ and $\mathrm{N}$ ecosystem cycling, such as plant growth, mineralization, plant and microbial $\mathrm{N}$ immobilization, nitrification and denitrification on daily, monthly and annual scales. In models such as the DNDC model [ $\mathrm{Li}$ et al., 2000] NO production in the soil is simulated as the result of simultaneous occurring production (nitrification and denitrification) as well as consumption processes (in DNDC only denitrification), the magnitude of both processes being dependent on the actual environmental conditions. The disadvantage of process-based models is their need for comprehensive site descriptions, with complete soil and stand properties and detailed information on a series of environmental descriptors. This is deterrent when large scale (regional or global) inventories have to be elaborated, since relevant information on these scales is hard to obtain or have a distinct uncertainty (e.g., soil properties). For that reason, $\mathrm{ANN}$ is an alternative for building or improving $\mathrm{NO}$ emission inventories at different scales, with a few numbers of environmental parameters.

[8] In this work we used ANN methodology to explore its capability to simulate observed multiyear seasonal variations of NO fluxes at a temperate forest site. For this, the existing data set was split in a 4 year (1994-1997) and a 2-year (2002-2003) period, with the first one being used to evaluate ANN predictive performance. The second period (2002-2003), for which continuous NO emission measurements are available, has been used as an independent test period for ANN and for comparison with simulation results using the detailed process oriented model PnET-N-DNDC.

\section{Method}

\subsection{Site Description}

[9] Field measurements of in situ NO fluxes were performed in an 80-year-old coniferous (Norway spruce, Picea abies L.) and a 90-year-old beech (Fagus sylvatica L.) plantation in the Höglwald forest. This site is located $40 \mathrm{~km}$ north-west of the city of Munich, Germany, in a region characterized by a mixture of forested and intensively used agricultural areas [Kreutzer and Weiss, 1998]. NO in situ fluxes were measured at three different types of sites: spruce (called spruce control), spruce-limed and beech. The soil is an acid hapludalf (US Soil Taxonomy, Soil Survey Staff, 1973) (dystric cambisol: FAO/UNESCO, 1988). Soil characteristics of the spruce (control and limed) and beech sites investigated are summarized by Kreutzer [1995]. Liming of spruce site was performed in March 1994 by surface application of $4 \mathrm{t}$ dolomite $\mathrm{ha}^{-1}$. NO fluxes at the forest soil-atmosphere interface were measured continuously all year-round since November 1993 at both spruce sites and since mid of August 1994 at the beech site. NO fluxes were measured with 5 static or 5 dynamic chambers (dimensions: $0,5 \mathrm{~m} * 0,5 \mathrm{~m} * 0,15 \mathrm{~m}$ ) at each site [Butterbach-Bahl et al., 1997] at a temporal resolution of $1 \mathrm{~h} . \mathrm{pH}$ and soil texture 
Table 1. Database Description

\begin{tabular}{cccccc}
\hline Sample & $\begin{array}{c}\text { NO Mean, } \\
\mathrm{gN} / \mathrm{ha} / \mathrm{d}\end{array}$ & $\begin{array}{c}\text { Min/Max } \\
\mathrm{T},{ }^{\circ} \mathrm{C}\end{array}$ & $\begin{array}{c}\text { Min/Max } \\
\text { WFPS, \% }\end{array}$ & $\begin{array}{c}\text { Mean } \\
\text { Humus pH }\end{array}$ & $\begin{array}{c}\text { Number of } \\
\text { Examples }\end{array}$ \\
\hline $\begin{array}{c}1994-1997 \\
\text { Spruce control } \\
1994-1997 \\
\text { Spruce-limed } \\
1994-1997\end{array}$ & 21.6 & $-2.8 / 22.8$ & $51.4 / 76.2$ & 3.1 & 1403 \\
$\begin{array}{c}\text { Beech } \\
1994-1997\end{array}$ & 7.6 & $-2.8 / 22.8$ & $51.4 / 76.2$ & 5.9 & 1020 \\
$\begin{array}{c}\text { Spruce control } \\
\text { 2002-2003 }\end{array}$ & 3.05 & $-2.0 / 17.7$ & $41.4 / 92.0$ & 4.0 & 1104 \\
\hline
\end{tabular}

were measured once every 6 months. During the 4-year measurements period (between 94 and 97), $\mathrm{pH}$ value did not change. Nitrification and denitrification rates were measured monthly, $\mathrm{N}$ content, $\mathrm{C}$ content and $\mathrm{C} / \mathrm{N}$ biweekly. Details about the measurements, the equipment used, analytical conditions, temporal resolution and calculation procedures are given by Butterbach-Bahl et al. [1997, 1998], Papen and Butterbach-Bahl [1999], Gasche and Papen [1999], Gasche et al. [2002].

[10] Air humidity and soil temperatures are measured in situ. Water Filled Pore Space (WFPS) are extracted from PnET-N-DNDC model and validated with in situ measurements. WFPS determines the percentage of soil pore occupied by water. It is defined as the ratio between volumetric humidity and soil porosity:

$$
\% \text { WFPS }=100 \cdot \mathrm{H}_{\nu} /(1-(\mathrm{db} / \mathrm{ds}))
$$

with $\mathrm{H}_{\nu}$ : soil volumetric humidity, $\mathrm{db}$ and $\mathrm{ds}$ : bulk density and soil density.

[11] Air Humidity, Air Temperature, Surface (humus) temperature and WFPS, temperature and WFPS at 5, 10, 15 , and $20 \mathrm{~cm}$ depth were measured and presented as daily means in the database. During the experiment, the following 19 soil parameters were measured, but were only available as mean values for each database: humus $\mathrm{C} / \mathrm{N}$ ratio, humus $\mathrm{pH}$, mineral $\mathrm{C} / \mathrm{N}$ ratio, mineral soil $\mathrm{pH}$, humus $\mathrm{C}$ content, soil texture (sand, clay, silt), mean $0-40 \mathrm{~cm}$ depth $\mathrm{C}$ content, mean $0-10 \mathrm{~cm}$ depth density, mean $0-100 \mathrm{~cm}$ depth $\mathrm{C}$ content, $30 \mathrm{~cm}$ depth density, total $\mathrm{C}$ content, nitrification rate [Gasche et al., 2002], humus N content, potential denitrification rate (Gasche, unpublished data), mean $0-40 \mathrm{~cm}$ depth $\mathrm{N}$ content, humus thickness, mean 0-100 cm depth $\mathrm{N}$ content.

\subsection{Statistical Analyses: Neural Network}

[12] ANN generates a nonlinear equation that parameterizes NO fluxes (outputs) from determining parameters (inputs). The advantage of using an ANN rather than other non linear regression method is the possibility to include several determining parameters while keeping the rapidity and efficiency of the calculation.

[13] The equation is a combination of inputs $\left(\mathrm{x}_{\mathrm{i}}\right)$, weights $\left(\mathrm{w}_{\mathrm{i}}\right)$ and a constant term called "bias" $\left(\mathrm{w}_{0}\right)$ :

$$
u=w_{0}+\sum_{i=1}^{i=n-1} w_{i} \times x_{i}
$$

Weights are calculated iteratively and attributed to each input in order to generate the minimal difference between measured and calculated outputs [Dreyfus et al., 2002]. The set of input data used by the neural network is divided in two parts, the training set (2/3 of the whole database) and the validation set ( $1 / 3$ of the whole database). Both sets were determined so that after partitioning the same statistical distribution is given. The learning process will determine a set of weights, which will then be applied on the validation set, i.e., a data set which was not used for model development. Then, learning and validation costs (i.e., Root Mean Square Error (RMSE) between measured and calculated values for each set) are calculated from this partitioning. Both costs need to be minimized, which means that the model output closely mirrors all the training points. The architecture of the ANN depends on the number of hidden neurons, directly affecting learning and validation costs. (Hidden neurons realize a linear combination of input parameters and their respective weights. Afterward, a non linear regression (using the hyperbolic tangent mathematical function) is done to determine biogenic NO fluxes). Choosing the good number of hidden neurons is determinant to avoid over fitting, leading to an augmentation of the validation cost. Not enough neurons will result in not reaching the closest solution, whereas too many of them will induce a noisy solution. After several tests, the most appropriate number of hidden neurons is chosen.

[14] The capacity to extract the usable information from a sample of data is given by the generalization cost, which is an indicator of networks performances, and has to be as small as possible. It represents the capacity of the model to interpolate between points, and the generalization performance is tested using the validation set [Gardner and Dorling, 1999].

[15] The homogeneity is also a quality index, and is available to determine the best parameterization. It represents the capacity of the network to take into a well balanced account all the examples (lines) of the database. Homogeneity is calculated from the learning set and has to be as small as possible. In this study, we will use validation and generalization costs, and homogeneity values to evaluate ANN performances.

[16] Maximal number of epochs (or number of modifications in weight values) used in the optimization is 100 . Ten initializations (or 10 series of different sets of weights) are tested for each model. This configuration (100 epochs, 10 models) is tested several times in order to avoid a local minimum solution. The transfer function (the mathematical

Table 2. Comparison of Quality Criteria for 4 to $11 \mathrm{HN}$ Models on Spruce Control Database (1994-1997)

\begin{tabular}{lcccc}
\hline Networks & $\begin{array}{c}\text { Learning } \\
\text { Cost }\end{array}$ & $\begin{array}{c}\text { Validation } \\
\text { Cost }\end{array}$ & $\begin{array}{c}\text { Generalization } \\
\text { Cost }\end{array}$ & Homogeneity \\
\hline $4 \mathrm{HN}$ & 8.375 & 9.809 & 8.772 & 0.921 \\
$5 \mathrm{HN}$ & 8.065 & 9.614 & 8.682 & 0.897 \\
$6 \mathrm{HN}$ & 8.047 & 9.639 & 8.673 & 0.91 \\
$7 \mathrm{HN}$ & 7.517 & 9.657 & 8.479 & 0.929 \\
$8 \mathrm{HN}$ & 7.499 & 9.141 & 8.470 & 0.916 \\
$9 \mathrm{HN}$ & 7.401 & $\mathbf{8 . 6 8 4}$ & $\mathbf{8 . 3 8 0}$ & $\mathbf{0 . 9 3 1}$ \\
$10 \mathrm{HN}$ & 6.894 & 8.773 & 8.505 & 0.912 \\
$11 \mathrm{HN}$ & 6.841 & 9.334 & 9.278 & 0.928 \\
\hline
\end{tabular}


Table 3. Comparison of Quality Criteria for 3 to $8 \mathrm{HN}$ Models on Spruce-Limed Database (1994-1997)

\begin{tabular}{lcccc}
\hline Networks & $\begin{array}{c}\text { Learning } \\
\text { Cost }\end{array}$ & $\begin{array}{c}\text { Validation } \\
\text { Cost }\end{array}$ & $\begin{array}{c}\text { Generalization } \\
\text { Cost }\end{array}$ & Homogeneity \\
\hline $3 \mathrm{HN}$ & 5.224 & 5.905 & 5.998 & 0.854 \\
$4 \mathrm{HN}$ & 5.234 & 5.882 & 5.713 & 0.894 \\
$5 \mathrm{HN}$ & 4.938 & 5.537 & 5.041 & 0.947 \\
$6 \mathrm{HN}$ & 4.535 & 5.187 & 5.090 & 0.933 \\
$7 \mathrm{HN}$ & 4.301 & $\mathbf{5 . 1 2 6}$ & $\mathbf{4 . 9 5 0}$ & $\mathbf{0 . 9 4 7}$ \\
$8 \mathrm{HN}$ & 4.265 & 5.400 & 5.435 & 0.933 \\
\hline
\end{tabular}

function) is a hyperbolic tangent. Finally, the network is used in a static version, which implies that input and output values are considered as independent of each other.

[17] A broader description of ANN and associated costs may be found by Delon et al. [2007] and references therein. This article gives an insight of the ANN method used with both tropical and temperate data sets. The data are different from those of this study, but the method is comparable. The neural network used in this study was based on a commercial version of the Neuro One 6.9 (c) software, (Netral, Issy les Moulineaux, France).

[18] To optimize ANN performance, input parameters have to be selected considering their redundancy and relevancy. To delete redundant parameters, a linear correlation factor study is done between the different temperatures, humidity and soil parameters. Indeed, introducing redundant data into ANN database increases calculation costs and does not bring interesting information to the network. After redundant data deletion, a classification of relevant param- eters is done with the Gram-Schmidt factor (GS). GS are expressed in percentage and determine the linear (polynomial) relevance of every input with $\mathrm{NO}$ fluxes (output). Inputs with a GS value lower than $50 \%$ are abandoned. The highest the GS is, the most relevant is the input parameter [Dreyfus et al., 2002]. All input parameters are normalized and centered in order to have the same order of magnitude. In case of very different orders of magnitude between variables, small ones may have artificially lower influence during the training. After the 10 initializations, the best algorithm within the 10 launched is chosen, by assessing the following four criteria.

[19] 1. Generalization costs are classified by ascending value.

[20] 2. Homogeneities of the lowest generalization cost models are compared. If generalization costs are not too different, the model with higher homogeneity is preserved.

[21] 3. In order to identify an eventual artifact, validation cost of the selected model is compared to other ones. Selected model has to show one of the lowest validation cost.

[22] 4. Learning cost has to be as small as possible.

\section{Results}

[23] The whole Höglwald 94-97 database was made up with 3 sets of data obtained from the three different sites: spruce control, spruce-limed and beech. In the rest of the study, these four databases will be referenced as follows.

[24] 1. Spruce control 94-97.

[25] 2. Spruce-limed 94-97.

[26] 3. Beech 94-97.

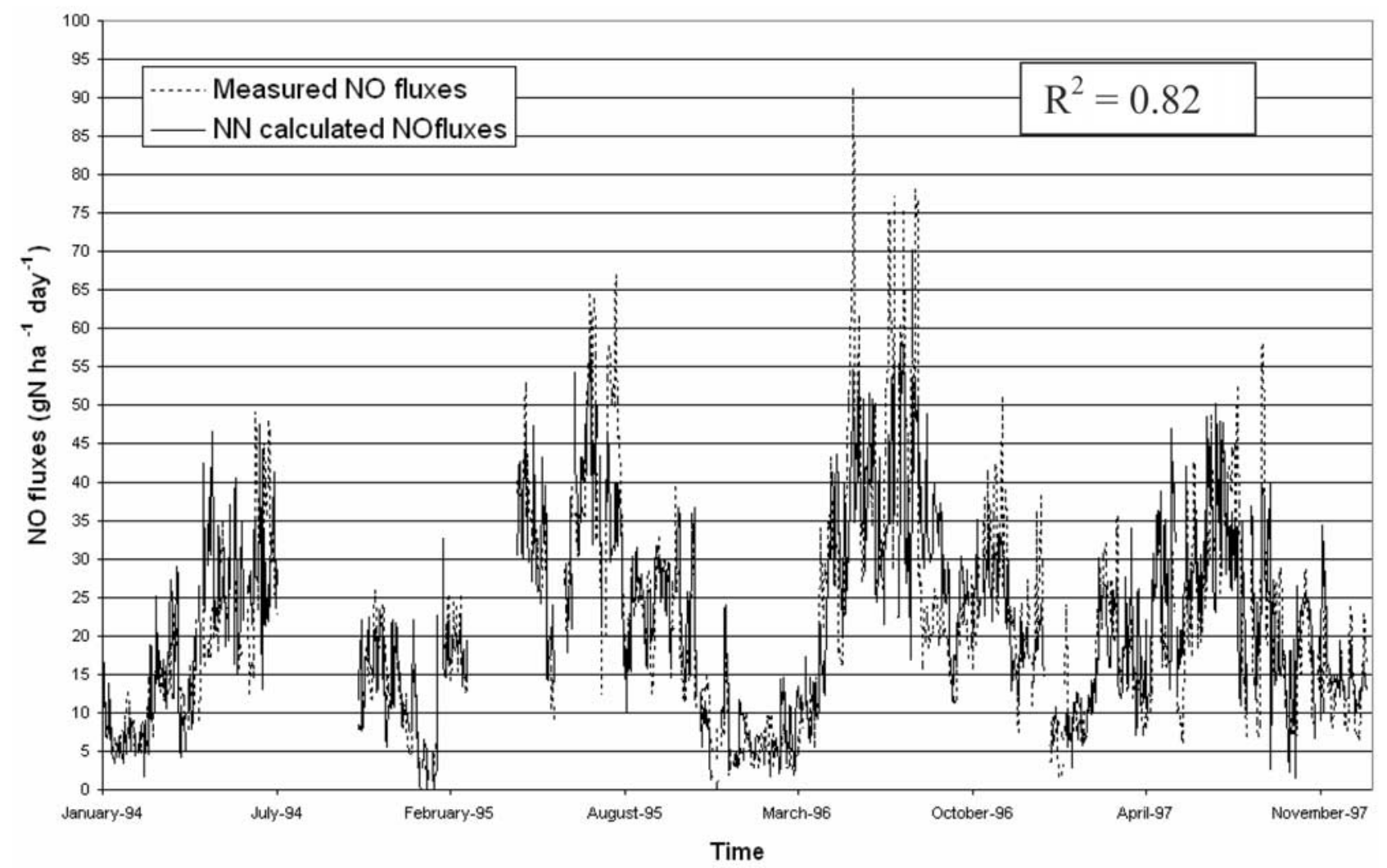

Figure 1. Measured and ANN model calculated NO emissions for the spruce control site (1994-1997). 


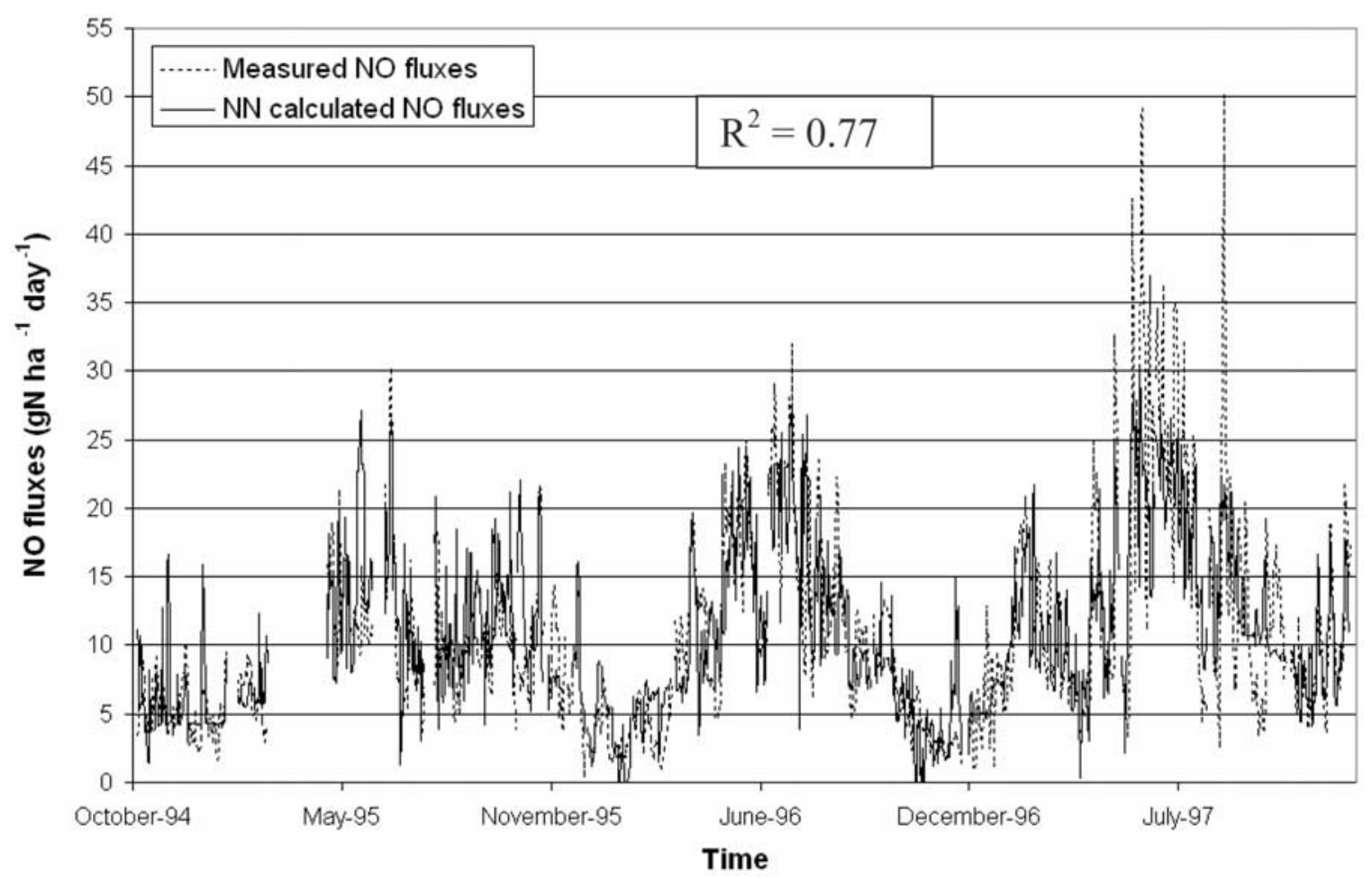

Figure 2. Measured and ANN model calculated NO emissions for the spruce-limed site (1994-1997).

[27] 4. Total Höglwald 94-97 (spruce control 94-97+ spruce-limed 94-97 + beech 94-97).

[28] A fifth database set is constituted by the $2002-2003$ measurements on the spruce control site, and will be referenced as Spruce control 02-03. Because of technical problems in measurements, databases can show daily missing lines, visible in the figures. The five data sets are presented in the Table 1 .

[29] Results are presented in a sequential way. ANN is run with NO fluxes as output. Data sets (spruce control 94-97, spruce-limed 94-97 and beech 94-97) are processed independently. For each data set, the relevance of each input parameter and the efficiency of hidden neurons number are discussed.

[30] The three sets are mixed and processed to obtain the Total Höglwald 94-97 database. Each of the individual data set has the same weight in the total database (equivalent number of lines in the three individual sets). Finally, Total Höglwald and spruce control 94-97 parameterizations are used to predict 2002-2003 NO fluxes, and are compared to in situ measurement and PnET-N-DNDC model results.

\subsection{Spruce Control 94-97 Parameterization}

[31] Considering the high number of available inputs (31 inputs: air temperature and humidity, 5 soil temperatures, 5 soil WFPS and 19 soil parameters) and their possible redundancy, a correlation study is first done to remove non relevant parameters. According to their redundancy with $10 \mathrm{~cm}$ depth soil temperature and their lowest line number representation, soil temperature measurements at $5 \mathrm{~cm}$ and $15 \mathrm{~cm}$ depth are not considered. Similarly, $15 \mathrm{~cm}$ WFPS, redundant with the other WFPS values, is not taken into account. The 19 mean parameters describing the soil are provided as constant values in the database during the whole measurement period. They are not relevant for explaining the seasonality of NO fluxes, and, therefore, are not kept as input parameters. This first selection of input parameters leads to a database with nine driving parameters, i.e.: air temperature, air humidity, soil temperatures at surface, $10 \mathrm{~cm}$ depth and $20 \mathrm{~cm}$ depth, and WFPS at surface (humus), $5,10 \mathrm{~cm}$, and $20 \mathrm{~cm}$ depth.

[32] A second selection was made by calculating the Gram-Schmidt factor to evaluate the relevance of each input parameters. The Gram-Schmidt (GS) factor is evaluated on a first three hidden neurons $(\mathrm{HN})$ model. This factor is independent of the hidden neurons number, and only fluctuates with database characteristics. Therefore in all this study, GS factors will be calculated with three hidden neurons. This evaluation shows that surface (humus) WFPS is non relevant as a control of NO fluxes.

[33] Quality controls are performed on the results by comparing learning, validation, and generalization costs and homogeneity.

[34] Next step is to improve the model performances by increasing the number of HN. Table 2 shows a decrease in learning costs when $\mathrm{HN}>9$. The displayed validation costs

Table 4. Comparison of Quality Criteria for 3 to $9 \mathrm{HN}$ Models on Beech Database (1994-1997)

\begin{tabular}{lcccc}
\hline Networks & $\begin{array}{c}\text { Learning } \\
\text { Cost }\end{array}$ & $\begin{array}{c}\text { Validation } \\
\text { Cost }\end{array}$ & $\begin{array}{c}\text { Generalization } \\
\text { Cost }\end{array}$ & Homogeneity \\
\hline $3 \mathrm{HN}$ & 3.112 & 3.815 & 3.381 & 0.880 \\
$4 \mathrm{HN}$ & 3.119 & 3.726 & 3.460 & 0.880 \\
$5 \mathrm{HN}$ & 2.773 & 3.929 & 3.078 & 0.919 \\
$6 \mathrm{HN}$ & 2.523 & 3.829 & $\mathbf{2 . 8 3 9}$ & $\mathbf{0 . 9 3 2}$ \\
$7 \mathrm{HN}$ & 2.463 & 3.769 & 3.025 & 0.917 \\
$8 \mathrm{HN}$ & 2.513 & $\mathbf{3 . 4 0 7}$ & $\mathbf{2 . 8 3 9}$ & 0.926 \\
$9 \mathrm{HN}$ & 2.459 & 3.708 & 3.047 & 0.931 \\
\hline
\end{tabular}




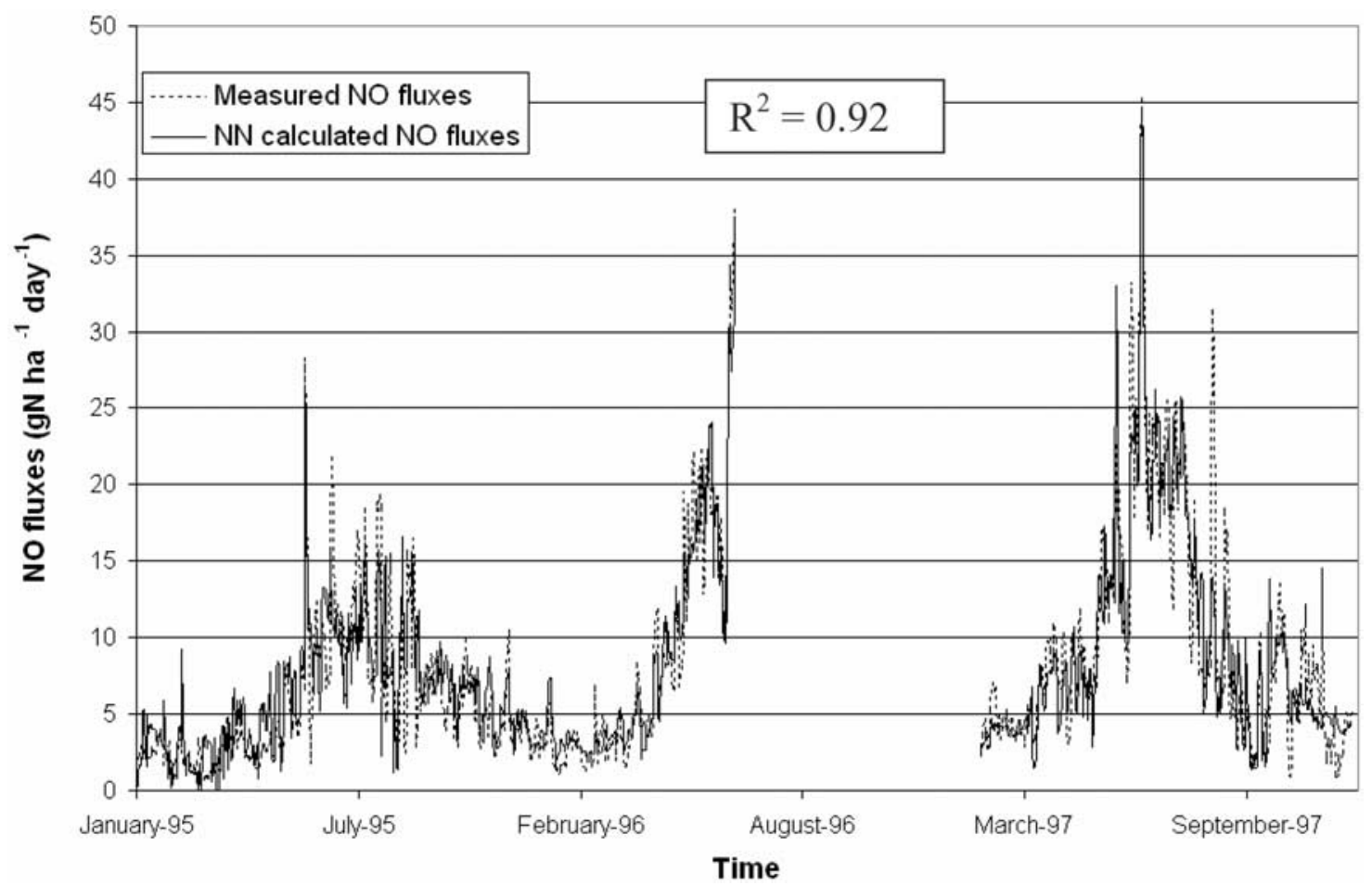

Figure 3. Measured and ANN model calculated NO emissions for the beech site (1994-1997).

are decreasing till 8.684 (bold in Table 2) for a $9 \mathrm{HN}$ model. The increase observed for $\mathrm{HN}>9$ indicates over fitting, and shows that the performance of the network is degrading.

[35] The $9 \mathrm{HN}$ model is presenting the best generalization cost (8.380, bold in Table 3$)$ and the best homogeneity.

[36] The final $\mathrm{NO}$ flux model $(9 \mathrm{HN})$ is presented in Figure 1, and shows that low (seasonal) and high frequency (diurnal) variations are well represented for the entire period of observations, with a correlation factor $\mathrm{R}^{2}$ equal to 0.82 . The chosen parameterization seems to have problems to fit the highest fluxes, and an underestimation of NO fluxes by the ANN model occurs for values exceeding $50 \mathrm{gN} \mathrm{ha}^{-1} \mathrm{~d}^{-1}$. However the ANN parameterization determines an average calculated flux of $21.6 \mathrm{gN} \mathrm{ha} \mathrm{d}^{-1}$, equal to the average measured fluxes for the same period and site. The ANN performance is very encouraging with regards to high and low frequency variations, and to the estimation of the average site NO flux (error $<1 \%$ ).

\subsection{Spruce-Limed 94-97 Parameterization}

[37] The ANN model was applied for the spruce-lime site. This site was limed in 1994, with a subsequent increase of the forest soil $\mathrm{pH}$ from 3.05 to 5.9 , and an immediate decrease in NO emissions [Gasche and Papen, 1999]. In that site, as for the spruce control site, the 19 soil mean parameters are constant during the whole measurement period, and are not considered. After checking correlations between meteorological data and line number representation, soil $5 \mathrm{~cm}$ and $15 \mathrm{~cm}$ depth temperatures are abandoned $\left(\mathrm{R}^{2}=0.99\right.$ with $10 \mathrm{~cm}$ depth temperature). As for the first ANN analysis, the study started with a $3 \mathrm{HN}$ model. A Gram-Schmidt factor analysis shows that 10 and $15 \mathrm{~cm}$ depth WFPS are non relevant. The input set is therefore constituted of 8 parameters, i.e.: air temperature and humidity, surface, $10 \mathrm{~cm}$ and $20 \mathrm{~cm}$ depth temperature and surface, $5 \mathrm{~cm}, 20 \mathrm{~cm}$ depth WFPS.

[38] Table 3 shows that the best validation and generalization costs and homogeneity are observed for a $7 \mathrm{HN}$ model. This $7 \mathrm{HN}$ model is run with the 8 above-listed inputs parameters to parameterize NO fluxes. Figure 2 compares calculated (full lines) and measured (dotted lines) NO fluxes for the spruce-limed site.

[39] The developed ANN model captures well the high and low frequency variations of NO fluxes. The overall correlation factor is 0.77 , i.e., slightly lower than $\mathrm{R}^{2}$ calculated for the control site. The ANN model provides a good representation for periods with high NO fluxes for the years 1994 to 1996, but seems to underestimate peak NO emissions in the year 1997. The underestimation of peak NO flux in year 1997 clearly appears for fluxes above $30 \mathrm{gN} \cdot \mathrm{ha}^{-1} \cdot \mathrm{d}^{-1}$, whereas fluxes under $30 \mathrm{gN} \cdot \mathrm{ha}^{-1} \cdot \mathrm{d}^{-1}$ are well represented. The observed increase in $\mathrm{NO}$ emissions in the year 1997 is likely to result from a reacidification of the forest soil, consecutive to a weakening of the liming effect.

Table 5. Comparison of Quality Criteria for Models Performed on Total Höglwald Database (1994-1997)

\begin{tabular}{lcccc}
\hline \multicolumn{1}{c}{ Networks } & Learning & Validation & Generalizsation & Homogeneity \\
\hline 8HN (10 data + pH humus) & $\mathbf{7 . 0 2 9}$ & $\mathbf{7 . 2 2 3}$ & $\mathbf{7 . 2 1 5}$ & $\mathbf{0 . 9 2 3}$ \\
7HN (10 data + C/N humus) & 6.630 & 7.560 & 6.830 & 0.91 \\
7HN (10 data + N humus content) & 8.500 & 8.550 & 8.790 & 0.92 \\
\hline
\end{tabular}




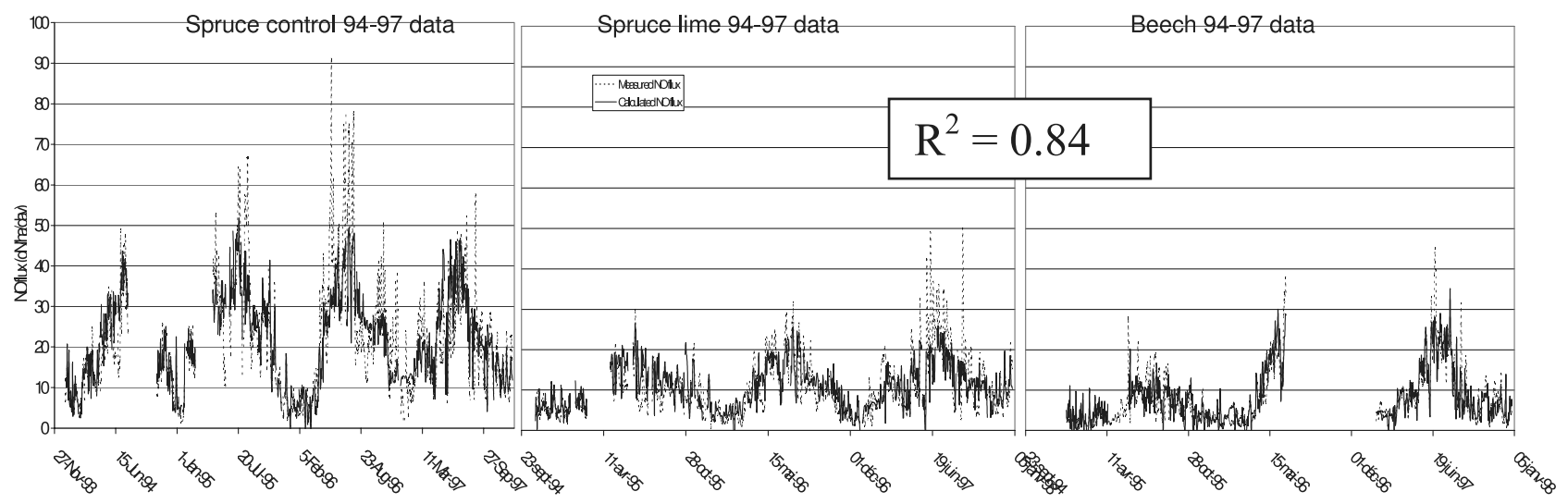

Figure 4. Measured and ANN model calculated NO emissions for the different sites at the Höglwald Forest using one global parameterization for the years 1994-1997.

Since in our model we considered $\mathrm{pH}$ as a constant, such an acidification effect on NO fluxes cannot be simulated. However, as for the control site, mean average measured and calculated NO fluxes are very close, respectively 10.7 and $10.6 \mathrm{gN} \cdot \mathrm{ha}^{-1} \cdot \mathrm{d}^{-1}$, with a relative error below $1 \%$.

\subsection{Beech 94-97 Parameterization}

[40] After checking correlations and parameters availability, 10,15 , and $20 \mathrm{~cm}$ depth soil temperatures, redundant with surface and $5 \mathrm{~cm}$ depth soil temperature, are abandoned. $15 \mathrm{~cm}$ depth WFPS is also not taken into account because of its redundancy with other soil WFPS. GramSchmidt factors calculation on a $3 \mathrm{HN}$ model leads to the skipping of $5 \mathrm{~cm}$ depth WFPS from the input parameter set. Then, the study is done on a 7 input parameters database, with 3 to $9 \mathrm{HN}$ model analysis. Results are presented in Table 4.

[41] After optimization of validation and generalization costs, $8 \mathrm{HN}$ are selected. Using this configuration, a 7-input parameterization is defined to generate NO fluxes. Figure 3 compares beech site calculated (full line) and measured (dotted line) NO fluxes time series.

[42] High and low frequency variations of calculated fluxes, including periods of peak emissions, are well simulated during the measurement period, with a high $\mathrm{R}^{2}$ (0.92). Mean average calculated and measured fluxes agree closely (calculated: $7.9 \mathrm{gN} \mathrm{ha}^{-1} \mathrm{~d}^{-1}$, measured: $7.8 \mathrm{gN} \mathrm{ha}^{-1} \mathrm{~d}^{-1}$ ), and mean predicting error of measured NO fluxes is less than $1 \%$.

\subsection{Total Höglwald 94-97 Parameterization}

[43] The input database uses 10 different input parameters deduced from the three databases previous analysis, i.e., air temperature and humidity, 4 soil temperatures (surface, $5 \mathrm{~cm}, 10 \mathrm{~cm}$, and $20 \mathrm{~cm}$ depth) and 4 WFPS (humus, $5 \mathrm{~cm}, 10 \mathrm{~cm}$, and $20 \mathrm{~cm}$ depth). Total Höglwald 94-97 database is used to develop a temporally (diurnal and seasonal cycle) and spatially (3 implemented site) resolved parameterization. In that database, the 19 soil parameters are first kept. After a first Gram-Schmidt analysis with a $3 \mathrm{HN}$ model, 5 of these 19 parameters are kept as inputs: Humus $\mathrm{pH}$, Humus $\mathrm{C} / \mathrm{N}$ ratio and Humus $\mathrm{N}$ content, as well as nitrification rates and potential denitrification. The other 14 remaining parameters were excluded by the GS factor analysis because of their low spatial variation from site to site, leading to low relevance to explain fluxes variation. However, when these 5 parameters are included together in the database, results are not satisfying (not shown here). Consequently, each of these 5 parameters is considered individually. Table 5 shows a comparison of quality criteria for the best models obtained step by step.

[44] Nitrification and denitrification rates are important parameters controlling NO production in soil. However, ANN could not allow us to extract reliable information from these parameters due to their small inter sites variability (64.2\% to $66.6 \%$ for nitrification rate, and $33.4 \%$ to $35.8 \%$ for potential denitrification). Using humus $\mathrm{N}$ content as input parameter generates higher learning, validation and generalization costs than with humus $\mathrm{pH}$ and humus $\mathrm{C} / \mathrm{N}$ ratio. Humus $\mathrm{N}$ is then abandoned. After this selection, humus $\mathrm{pH}$ and $\mathrm{C} / \mathrm{N}$ ratio still remain as determinant parameters to describe $\mathrm{NO}$ soil emissions. $\mathrm{C} / \mathrm{N}$ ratio network gives a lower generalization cost, whereas the network with Humus $\mathrm{pH}$ gives a lower validation cost. Humus $\mathrm{pH}$ is therefore kept as input to generate the final NO fluxes parameterization (At this stage of the study, the purpose of this parameterization is to be validated on the Höglwald site, and not to be extrapolated at the regional scale.)

[45] The final parameter selection is defined as follows.

[46] - 11 input parameters: air temperature and humidity, 4 soil temperatures (surface, $5 \mathrm{~cm}, 10 \mathrm{~cm}$, and $20 \mathrm{~cm}$ depth) and 4 WFPS (humus, $5 \mathrm{~cm}, 10 \mathrm{~cm}$, and $20 \mathrm{~cm}$ depth) and humus $\mathrm{pH}$;

[47] $-8 \mathrm{HN}$.

[48] Figure 4 shows the seasonal variation of calculated (full lines) and measured (dotted lines) NO emissions for

Table 6. ANN Descriptions and Results on Spruce Control, Spruce-Limed, Beech and Total Hoëglwald 94-97 Databases

\begin{tabular}{|c|c|c|c|}
\hline Samples & Networks & $\begin{array}{c}\text { Relative Error } \\
\text { Between Measured } \\
\text { and Calculated } \\
\text { NO Fluxes }\end{array}$ & $\mathrm{R}^{2}$ \\
\hline Spruce control 94-97 & $9 \mathrm{HN}$ and 8 inputs & $<1 \%$ & 0.82 \\
\hline Spruce-limed 94-97 & $7 \mathrm{HN}$ and 8inputs & $<1 \%$ & 0.77 \\
\hline Beech 94-97 & $8 \mathrm{HN}$ and 7 inputs & $<1 \%$ & 0.92 \\
\hline Total Hoëglwald 94-97 & $8 \mathrm{HN}$ and 11 inputs & $<1 \%$ & 0.84 \\
\hline
\end{tabular}




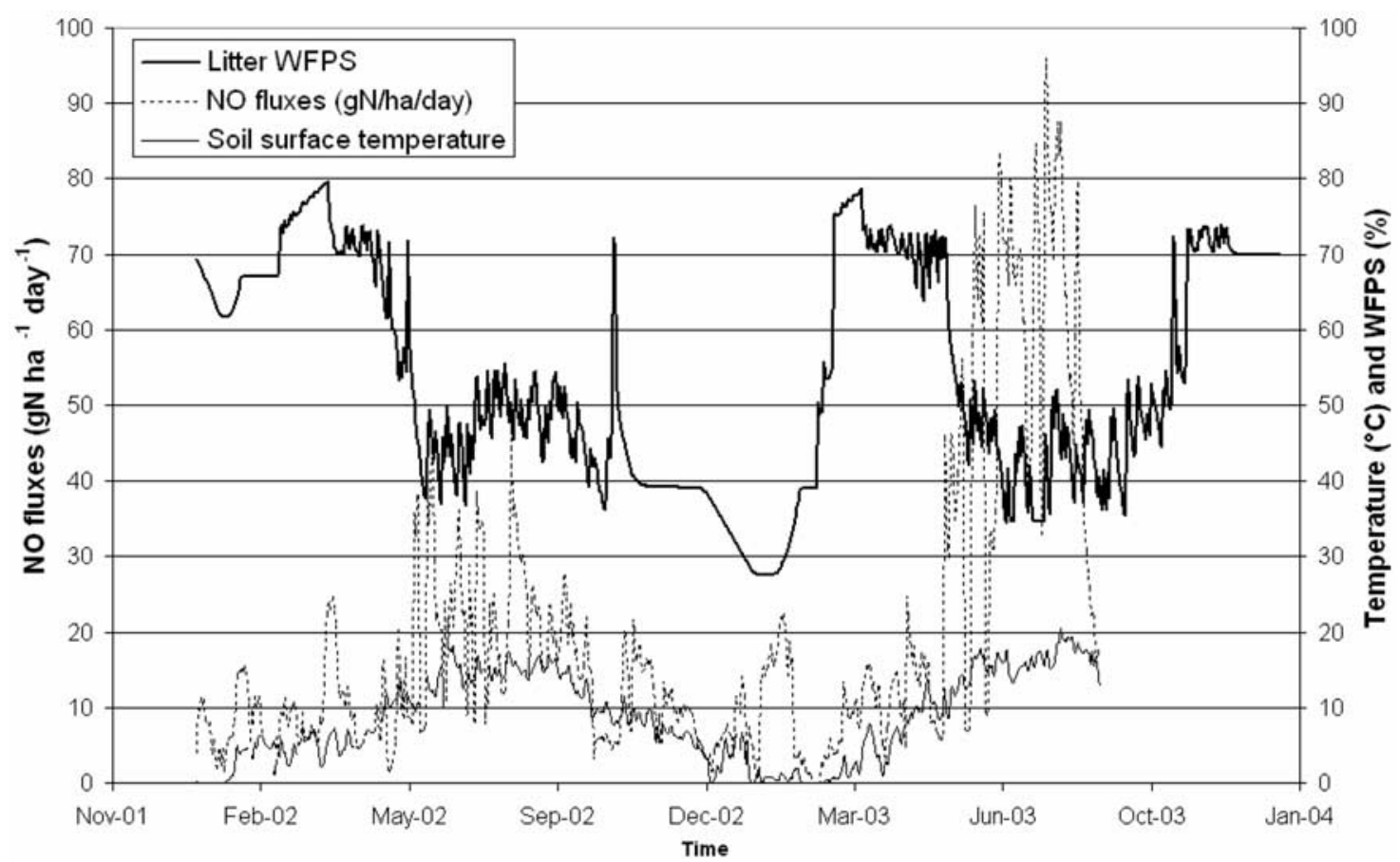

Figure 5. Observed NO fluxes (dotted line), soil temperature and PnET-N-DNDC modeled WFPS variations (bold plots) at the spruce control site of the Höglwald Forest in the years 2002-2003.

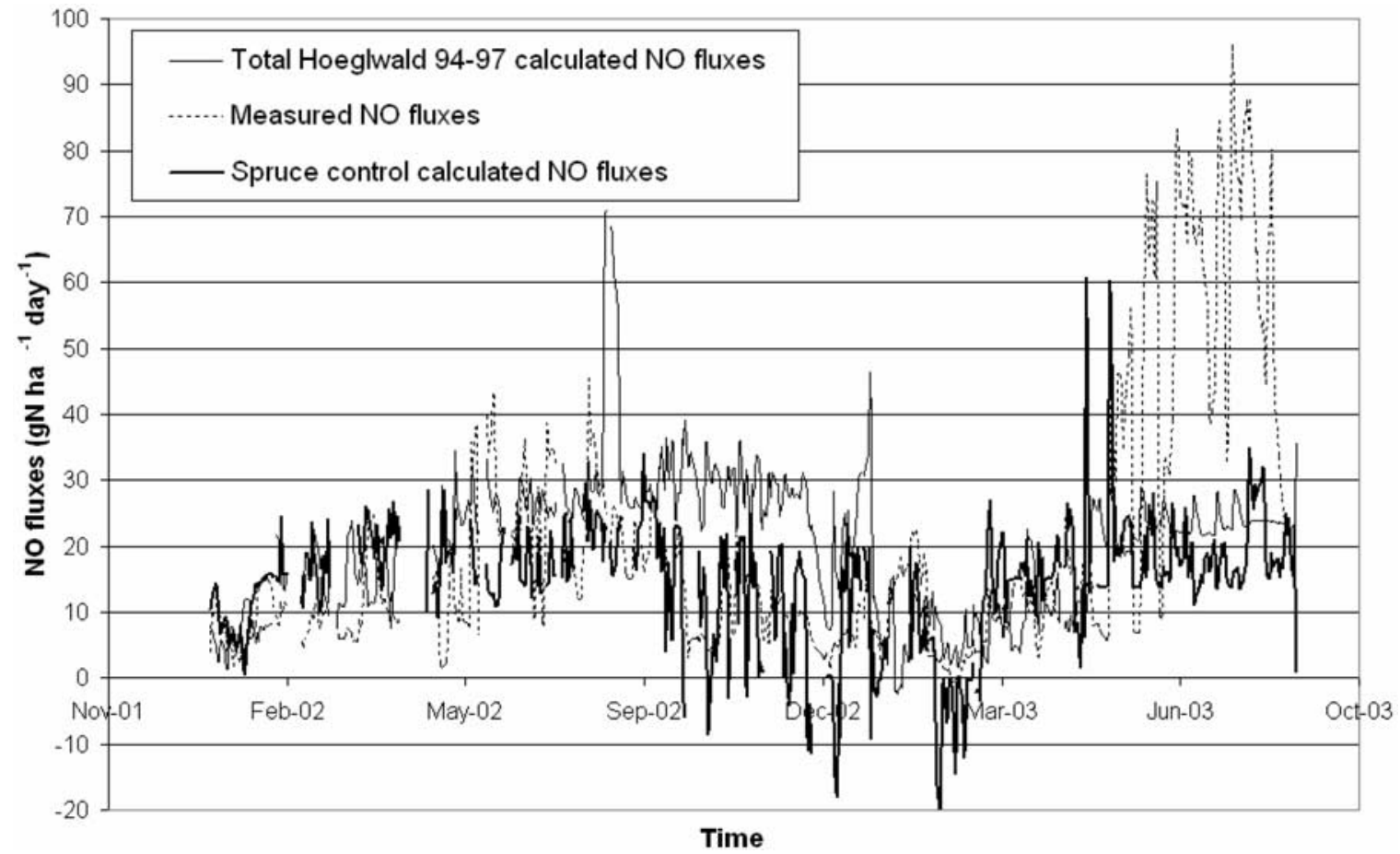

Figure 6. Total Höglwald neural networks simulation, spruce control neural networks simulation and in situ measurements on spruce control 2002-2003. 
Table 7. Comparison Between In Situ Measurements, Total Höglwald and Spruce Control Parameterization Results

\begin{tabular}{|c|c|c|c|}
\hline & $\begin{array}{l}\text { NO In Situ, } \\
\mathrm{gN} / \mathrm{ha} / \mathrm{d}\end{array}$ & $\begin{array}{c}\text { NN Total } \\
\text { Höglwald NO } \\
\text { Fluxes, gN/ha/d }\end{array}$ & $\begin{array}{c}\text { NN Spruce Control } \\
\text { NO Fluxes, } \\
\text { gN/ha/d }\end{array}$ \\
\hline NO means (2002-2003) & 21.7 & 15.3 & 14.6 \\
\hline $\begin{array}{l}\text { Correlation factor } \\
\quad(2002-2003)\end{array}$ & & 0.26 & 0.39 \\
\hline NO means (2002) & 13.6 & 14.9 & 14.9 \\
\hline Correlation factor (2002) & & 0.37 & 0.42 \\
\hline NO means (2003) & 42.7 & 16.3 & 14.2 \\
\hline Correlation factor (2003) & & 0.57 & 0.47 \\
\hline
\end{tabular}

the Total Höglwald 94-97 database. Low and high frequency variations are well simulated. Then, calculated fluxes are close to measured data, giving averages of $14.6 \mathrm{gN} \mathrm{ha}^{-1} \mathrm{~d}^{-1}$ for both measured and calculated values. Neural network estimates the average flux with accuracy and well represents high and low frequency variations, with a correlation factor of 0.84 . The parameterization performances are encouraging, in view of simulating the seasonality of NO fluxes, and estimating the annual emissions (Table 6).

\subsection{2-2003 NO Fluxes Estimate and Results Comparison}

[49] In that section, we will use the 1994-1997 ANN parameterizations with the $02-03$ database as input data set, to test the ANN predicting performance on the spruce data set. The results are also compared to the detailed biogeochemical PnET-N-DNDC model results [Li et al., 2000; Kesik et al., 2005].

[50] NO flux measurements were performed from 1 January 2002 until 31 August 2003 giving a 608-line database. Input parameters for the $02-03$ database are in situ measured temperatures (surface, $5 \mathrm{~cm}, 10 \mathrm{~cm}, 15 \mathrm{~cm}$, and $20 \mathrm{~cm}$ depth) and various in situ soil parameters $(\mathrm{pH}, \mathrm{N}$ content...). Since no continuous measurements of soil moisture were performed, we completed the input data set with PnET-N-DNDC WFPS (humus, $5 \mathrm{~cm}, 10 \mathrm{~cm}, 15 \mathrm{~cm}$, and $20 \mathrm{~cm}$ depth).

[51] In Figure 5, measured NO fluxes (dotted line) are displayed with measured soil surface temperature (light black line) and modeled humus WFPS (bold black line).

[52] An important increase in NO emissions is observed during summer 2003. These high fluxes could be the consequence of the 2003 heat wave, but cannot be explained by in situ temperature and WFPS levels, which are quite comparable to 2002 levels. This particular situation is a challenging test for neural network parameterization.

[53] Figure 6 shows a comparison of Total Höglwald 9497 and spruce control (bold plots) ANN estimates with in situ measurements (dotted line). Observed high and low frequencies are well represented by the ANN. Means and correlation factors between in situ and ANN values are presented in Table 7, for 2002, 2003, and 2002-2003 periods.

[54] From this table, it is difficult to assess which of the two parameterizations gives the best result. Indeed, mean values are quite similar for the two parameterizations. The correlation factor between measurements and calculation gives a good result in the Total Höglwald case for the 2003 period, whereas they are better in the Spruce control case for the 2002 and $2002-2003$ periods.

[55] 2002-2003 measurements come from the same site as spruce control 1994-1997 data. The good correlation in the

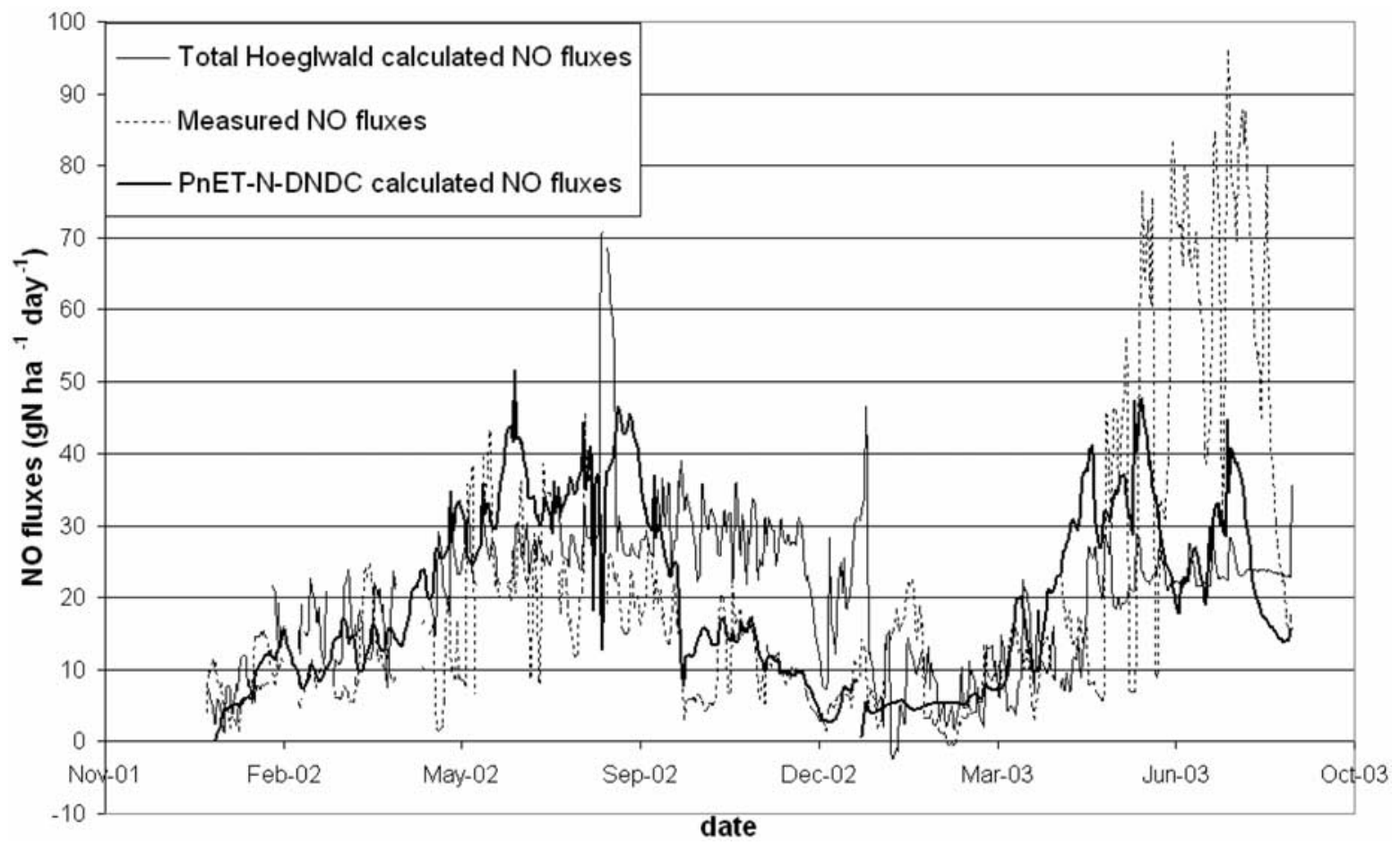

Figure 7. Neural networks, in situ and PnET-N-DNDC comparison for the spruce control (2002-2003) database. 
Table 8. Average Fluxes, and Correlation Comparison Between Total Höglwald Simulations, In Situ Measurement (2002-2003), and PnET-N-DNDC Outputs ${ }^{\mathrm{a}}$

\begin{tabular}{lccc}
\hline & $\begin{array}{c}\text { NO In Situ, } \\
\mathrm{gN} / \mathrm{ha} / \mathrm{d}\end{array}$ & $\begin{array}{c}\text { Neural Networks } \\
\mathrm{NO}, \mathrm{gN} / \mathrm{ha} / \mathrm{d}\end{array}$ & $\begin{array}{c}\text { PnET-N-DNDC } \\
\mathrm{NO}, \mathrm{gN} / \mathrm{ha} / \mathrm{d}\end{array}$ \\
\hline NO means (2002-2003) & 22.0 & $15.3(-30 \%)$ & $19.4(-12 \%)$ \\
Correlation factor & & 0.26 & 0.57 \\
$\quad(2002-2003)$ & & & \\
NO means (2002) & 15.3 & $14.9(-3 \%)$ & $19.6(+28 \%)$ \\
Correlation factor (2002) & & 0.37 & 0.73 \\
NO means (2003) & 30.6 & $16.3(-47 \%)$ & $19.2(-40 \%)$ \\
Correlation factor (2003) & & 0.57 & 0.71 \\
\hline
\end{tabular}

${ }^{\text {a }}$ Percentages between parentheses are calculated with respect to in situ values.

Spruce control case is therefore logical. However, due to its specificity, it is more sensible to parameters fluctuations and gives some unrealistic NO estimates between September 2002 and 2003, with strongly negative values (around $\left.-20 \mathrm{gN} \mathrm{ha}^{-1} \mathrm{~d}^{-1}\right)$.

[56] On the other hand, Total Höglwald 94-97 estimate, realized from a more generalist and therefore more robust parameterization, gives better results on average. This parameterization will be used in the following.

[57] Figure 7 presents a comparison between ANN Total Höglwald 94-97 simulation, PnET-N-DNDC estimate (bold plot) and in situ measurements (dotted line). Low frequency variations are well reproduced by the ANN parameterization. PnET-N-DNDC is also able to reproduce the seasonality, but also underestimates the summer 2003 high fluxes.
[58] Table 8 summarizes mean values and correlation factors for 2002, 2003 and 2002-2003 periods of experimental and simulated fluxes. For the 2002-2003 period, ANN and PnET-N-DNDC underestimate the measurements by respectively $30 \%$ and $12 \%$. Temporal variation is better simulated by PnET-N-DNDC $\left(\mathrm{R}^{2}=0.57\right)$ than ANN $\left(\mathrm{R}^{2}=\right.$ 0.26 ). For the 2002 period, ANN gives a very good estimate of NO fluxes, only $3 \%$ less than the measurements $(+28 \%$ for PnET-N-DNDC). 2002 period is well reproduced both by ANN (till September) and PnET-N-DNDC, when 2003 remains underestimated by both models.

[59] As a first conclusion, one can note that the Total Höglwald parameterization in predictive mode provides almost as good results as PnET-N-DNDC in terms of high and low frequency variations, and of mean fluxes. Next step to improve the results is to leave the predictive mode, and to fully provide the database with all fluxes.

[60] 2002-2003 data are mixed with the 1994-1997 ones in learning and validation data sets. A general parameterization is obtained from a $8 \mathrm{HN}$ model with 11 input parameters. Figure 8 displays a comparison between ANN calculated (solid line) and measured (dotted line) NO fluxes, and Figure 9 focuses on the 2002 and 2003 periods.

[61] Added in learning and validation sets, 2002-2003 fluxes bring essential information, allowing the calculated fluxes to fit in situ measurements. Correlation factor is now 0.81 , and mean values of measured and calculated fluxes are closer (respectively 22 and $23.7 \mathrm{gN} \mathrm{ha}^{-1} \mathrm{~d}^{-1}$ ) for the 2002-2003 period (see Table 9). A significant increase in correlation factors has to be mentioned for separated 2002 and 2003 periods. The global error between mean measured

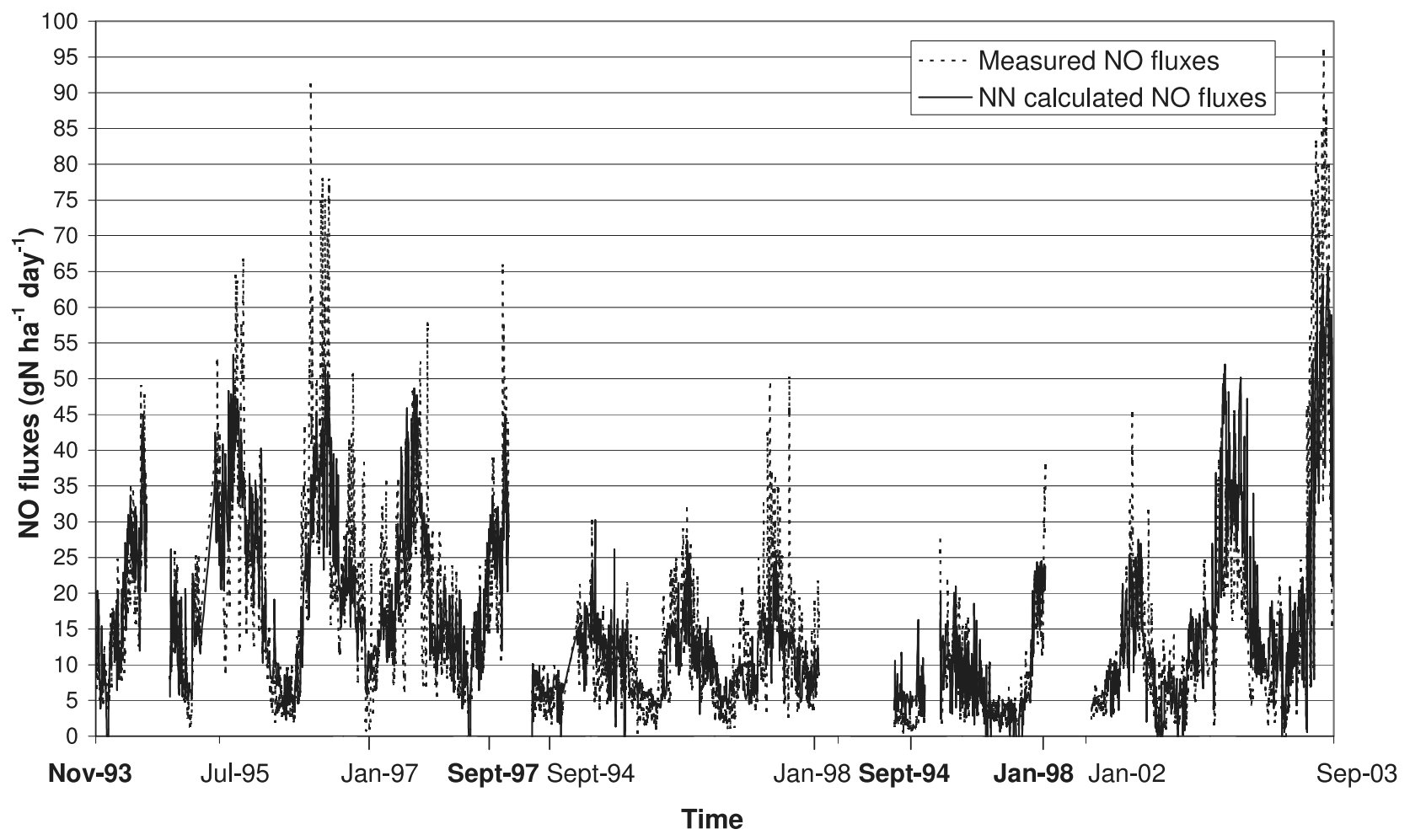

Figure 8. Compared variation of measured and calculated NO emissions for the 94-97+02-03 database. 


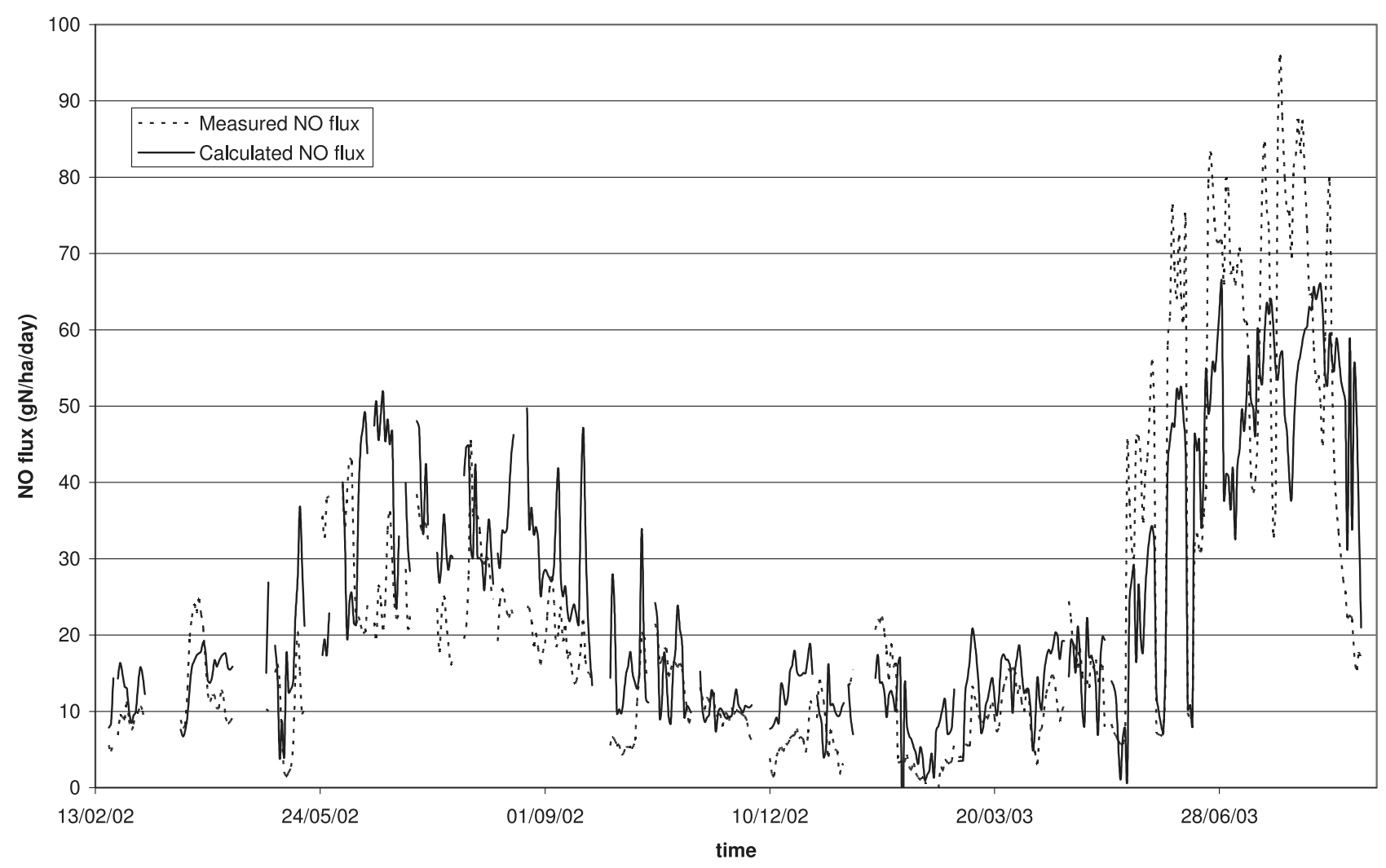

Figure 9. Calculated and measured NO fluxes comparison on (94-97+02-03) database for years 2002 and 2003.

and calculated fluxes is now reduced from -30 to $+8 \%$ for the whole period.

[62] This last study points out that the bigger and more resourceful the database is, the better the calculations will fit the measurements. To reduce calculation error and to be easily adaptable, parameterizations have to be built on the most important (in terms of number of lines) and variable (in situations) database.

\section{Conclusion}

[63] The aim of this work was to prove that ANN models could be used as a tool to reduce uncertainties on NO flux estimates from local to regional scales. As a first approach, we have applied the ANN concept to different sites of a temperate forest ecosystem in Germany for which detailed information on the magnitude and seasonality of fluxes were available. However, we are conscious that at the regional scale ANN approach will require further study and validation of the ANN methodology in variable situations, e.g., agricultural land use or prairies. As an alternative approach to biogeochemical models, we have used an ANN to define equations based on a set of general descriptors. Four parameterizations have been built from 3 site samples in 1994-1997: spruce control 94-97, spruce-limed 94-97, beech 94-97, and Total Höglwald 94-97 (the sum of the three previous ones). All input sets are composed of air, soil temperatures and WFPS at different depths, plus humus $\mathrm{pH}$ for Total Höglwald data set. All parameterizations represent well high and low frequency variations of
NO fluxes. Furthermore, estimated mean average fluxes are in good agreement with field measurements (error lower than one percent in all cases). Considering these results, 1994-1997 spruce control and Total Höglwald parameterizations are used to predict 2002-2003 spruce control NO fluxes. Results comparison indicates that both estimates are still well adapted to NO fluxes high and low frequency estimates. However, though ANN predictions for the year 2002 are in good agreement with field measurements, calculated NO fluxes for 2003 are significantly underestimated. The reason for this remains unclear, and would need more thorough analysis of the data. ANN estimates are in the same range as model results obtained with the biogeochemical PnET-N-DNDC model.

[64] To improve calculation results for the 2002-2003 period, 2002-2003 data are joined to the 1994-1997 data,

Table 9. Means and Correlation Comparison Between ANN Estimates and In Situ Measurement 2002-2003 ${ }^{\mathrm{a}}$

\begin{tabular}{lcc}
\hline & $\begin{array}{c}\text { NO In Situ, } \\
\mathrm{gN} / \mathrm{ha} / \mathrm{d}\end{array}$ & $\begin{array}{c}\text { Neural Networks NO, } \\
\mathrm{gN} / \mathrm{ha} / \mathrm{d}\end{array}$ \\
\hline NO means (2002-2003) & 22.0 & $23.7(+8 \%)$ \\
Correlation factor (2002-2003) & & 0.81 \\
NO means (2002) & 15.3 & $20.3(+25 \%)$ \\
Correlation factor (2002) & 30.6 & 0.71 \\
NO means (2003) & & $27.8(-9 \%)$ \\
Correlation factor (2003) & & 0.84 \\
\hline
\end{tabular}

${ }^{\text {a}}$ Percentages between parentheses are calculated with respect to in situ values. 


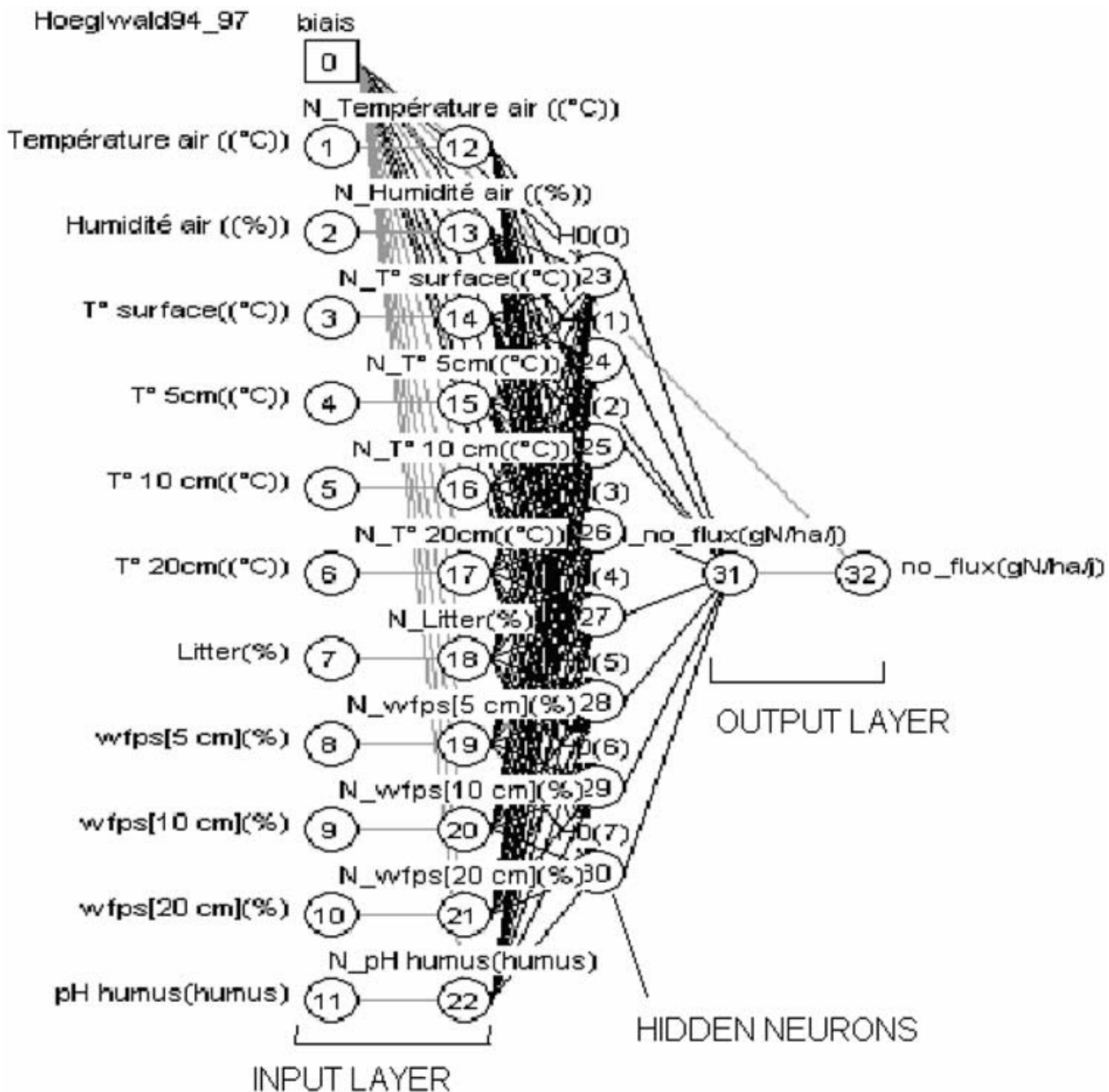

Figure A1. Total Höglwald 94-97 Networks Architecture: 11 input parameters and 8 Hidden Neurons Network.

and split in learning and validation data sets. The new parameterization significantly improves the results and the correlation factors for the period 2002-2003 periods. Furthermore, the difference between mean measured and simulated fluxes for this period decreases from $-30 \%$ to $+8 \%$. These results clearly show that a larger database covering multiple years and multiple sites is needed to improve estimates of NO fluxes. If neural network learns on different situations, it will have a better ability in reproducing specific phenomena, and will give a good estimate of $\mathrm{NO}$ fluxes at different scales To reduce calculation errors, and to be as widespread as possible, parameterizations have to be built on the most important (in lines) and variable (in situations) database.

[65] ANN is a promising tool for calculating regional $\mathrm{NO}$ flux inventories. This will require the development of a detailed database for a wider variety of ecosystems in different climate zones. Applied on European temperate forest area (around 141 millions ha), ANN average biogenic NO fluxes of $14.6 \mathrm{gN} \mathrm{ha}^{-1} \mathrm{~d}^{-1}$ estimated by the "total Höglwald" parameterization, gives an annual estimate of $747 \mathrm{kt} \mathrm{N} \mathrm{a}^{-1}$. Comparatively, Kesik et al. [2005], Simpson et al. [1999] and Skiba et al. [1992] have respectively obtained (for European forest soils), 44.4 to $254.0 \mathrm{kt} \mathrm{N}$ $\mathrm{a}^{-1}, 20 \mathrm{kt} \mathrm{N} \mathrm{a}^{-1}, 10$ to $300 \mathrm{kt} \mathrm{N} \mathrm{a}^{-1}$. This estimated emission calculated from this study seems to be overestimated, but does not take into account either the canopy uptake or the interannual variation of fluxes (considered as important by Kesik et al. [2005]). The above canopy emission would be decreased by a factor of 2 at the least, considering turbulent conditions, diurnal/nocturnal cycle of the boundary layer, and stomatic and cuticular absorption of $\mathrm{NO}_{2}$ onto leaf surface during night and day [Ganzeveld et al., 2002; Kirkman et al., 2002; Gut et al., 2002].

[66] Neural networks parameterizations reduce NO emissions uncertainties by taking into account the coupled impact of environmental parameters on soil NO emissions. Introduced in chemical models, they will help to improve comprehension of NO emissions (and consequently NOx impact) on atmospheric chemistry. In further work, and in order to study soil NO emission impact on atmospheric chemistry, the obtained equation will be introduced in a mesoscale coupled chemistry-dynamics model (Meso-NHChemistry, Lafore et al. [1998], Tulet et al. [2003]) or in a regional climate model (RegCM3, Pal et al. [2007]).

\section{Appendix A: Total Höglwald 94-97 Networks Architecture}

[67] 11 input parameters: air temperature and humidity, 4 soil temperatures (surface, 5, 10 and $20 \mathrm{~cm}$ depth), 4 WFPS (humus, $5 \mathrm{~cm}, 10 \mathrm{~cm}$, and $20 \mathrm{~cm}$ depth), humus $\mathrm{pH}$;

[68] 8 Hidden Neurons Network. (Figure A1) 


\section{References}

Anghel, C. I., and A. Ozunu (2006), Prediction of gaseous emissions from industrial stacks using an artificial intelligence method, Chem. Pap., 60(6), 410-415

Butterbach-Bahl, K., R. Gasche, L. Breuer, and H. Papen (1997), Fluxes of $\mathrm{NO}$ and $\mathrm{N}_{2} \mathrm{O}$ from temperate forest soils: Impact of forest type, $\mathrm{N}$ deposition and of liming on $\mathrm{NO}$ and $\mathrm{N}_{2} \mathrm{O}$ emissions, Nutr. Cycl. Agroecos., 48, 79-90.

Butterbach-Bahl, K., R. Gasche, C. Huber, K. Kreutzer, and H. Papen (1998), Impact of $\mathrm{N}$-input by wet deposition on $\mathrm{N}$-trace gas fluxes and $\mathrm{CH}_{4}$-oxidation in spruce forest ecosystems of the temperate zone in Europe, Atmos. Environ., 31, 559-564.

Davidson, E. A. (1991), Fluxes of nitrous oxide and nitric oxide from terrestrial ecosystems, in Microbial Production and Consumption of Greenhouse Gases: Methane, Nitrogen Oxides and Halomethanes, edited by J. E. Rogers, and W. B. Whitman, pp. 219-235, Am. Soc. for Microbiol., Washington.

Davidson, E. A., and W. Kingerlee (1997), A global inventory of nitric oxide emissions from soils, Nutr. Cycl. Agroecosyst., 48, 37-50.

Delmas, R., D. Serça, and C. Jambert (1997), Global inventory of NO sources, Nutr. Cycl. Agroecosyst., 48, 51-60.

Delon, C., D. Serça, C. Boissard, R. Dupont, A. Dutot, P. Laville, P. DeRosnay, and R. Delmas (2007), Soil NO emissions modelling using artificial neural network, Tellus, Ser. B, 59B, 502-513.

Dreyfus, G., J. M. Martinez, M. Samuelides, M. B. Gordon, F. Badran, S. Thiria, and L. Hérault (2002), Neural Network: Methodology and Applications (in French), Eyrolles, Paris.

Ganzeveld, L. N., J. Lelieveld, F. J. Dentener, M. C. Krol, A. J. Bouwman, and G. J. Roelofs (2002), Global soil-biogenic $\mathrm{NO}_{\mathrm{x}}$ emissions and the role of canopy processes, J. Geophys. Res., 107(D16), 4321, doi:10.1029/ 2001JD001289.

Gardner, M. W., and S. R. Dorling (1999), Neural network modelling and prediction of hourly $\mathrm{NO}_{\mathrm{x}}$ and $\mathrm{NO}_{2}$ concentrations in urban air in London, Atmos. Environ., 33, 709-719.

Gasche, R., and H. Papen (1999), A 3 year continuous record of nitrogen trace gas fluxes from untreated and limed soil of a N-saturated spruce and beech forest ecosystem in Germany: 2. NO and $\mathrm{N}_{2} \mathrm{O}$ fluxes, J. Geophys. Res., 104(D15), 18,505-18,520.

Gasche, R., K. Butterbach-Bahl, and H. Papen (2002), Development and application of a method for determination of net nitrification rates: Höglwald research II interdisciplinary investigations on nitrogen turnover in a nitrogen saturated forest ecosystem, Plant Soil, 240(1), 57-65.

Gut, A., et al. (2002), Exchange fluxes of $\mathrm{NO}_{2}$ and $\mathrm{O}_{3}$ at soil and leaf surfaces in an Amazonian rain forest, J. Geophys. Res., 107(D20), 8060, doi:10.1029/2001JD000654.

Houghton, R. A. (1996), Land-use change and terrestrial carbon: The temporal record, in Forest Ecosystems, Forest Management and the Global Carbon Cycle, edited by M. J. Apps, and D. T. Price, NATO ASI Ser, vol. I 40, pp. 117-134, Springer, Berlin.

Johansson, C., H. Rodhe, and E. Sanhueza (1988), Emission of NO in a tropical savanna and a cloud forest during the dry season, J. Geophys. Res., 93(D6), 7180-7192.

Kesik, M., et al. (2005), Inventories of $\mathrm{N}_{2} \mathrm{O}$ and $\mathrm{NO}$ emissions from European forest soils, Biogeosciences, 2, 353-375.

Kesik, M., S. Blagodatski, H. Papen, and K. Butterbach-Bahl (2006), Effect of $\mathrm{pH}$, temperature and substrate on $\mathrm{N}_{2} \mathrm{O}, \mathrm{NO}$ and $\mathrm{CO}_{2}$ production by Alcaligenes faecalis p., J. Appl. Microbiol., 101, 655-667.

Kirkman, G. A., A. Gut, C. Ammann, L. V. Gatti, A. M. Cordova, M. A. L. Moura, M. O. Andreae, and F. X. Meixner (2002), Surface exchange of nitric oxide, nitrogen dioxide, and ozone at a cattle pasture in Rondonia, Brazil, J. Geophys. Res., 107(D20), 8083, doi:10.1029/2001JD000523.

Kreutzer, K. (1995), Effects of forest liming on soil processes, Plant Soil, $168-169,447-470$.

Kreutzer, K., and T. Weiss (1998), The Höglwald field experiments - Aims, concept and basic data, Plant Soil, 199, 1-10.

Kroeze, C., et al. (1999), Closing the $\mathrm{N}_{2} \mathrm{O}$ budget: A retrospective analysis 1500-1994, Global Biochem. Cycles, 13(1), 1-8.

Lafore, J. P., et al. (1998), The Meso-NH Atmospheric Simulation System. part I: Adiabatic formulation and control simulations. Scientific objectives and experimental design, Ann. Geophys., 16, 90-109.
Li, C., J. C. Aber, F. Stange, K. Butterbach-Bahl, and H. Papen (2000), A process oriented model of $\mathrm{N}_{2} \mathrm{O}$ and $\mathrm{NO}$ emission from forest soils: 1. Model development, J. Geophys. Res., 105(D4), 4369-4385.

Martin, R. E., M. C. Scholes, A. R. Mosier, D. S. Ojima, E. A. Holland, and W. J. Parton (1998), Controls on annual emissions of nitric oxide from soils of the Colorado shortgrass steppe, Global Biogeochem. Cycles, 12(1), $81-91$

Mc Taggart, I. P., et al. (2002), Influence of soil physical properties, fertiliser type and moisture tension on $\mathrm{N}_{2} \mathrm{O}$ and $\mathrm{NO}$ emissions from nearly saturated Japanese upland soils, Nutr. Cycl. Agroecosyst., 63(2-3), 207217

Meixner, F. X., and W. X. Yang (2004), Biogenic emissions of nitric oxide and nitrous oxide from arid and semi-arid land, in Dryland Ecohydrology, edited by P. D'Odorico and A. Porporato, pp. 23-46, Springer, Dordrecht, Netherlands.

Müller, J. (1992), Geographical distribution and seasonal variation of surface emissions and deposition velocities of atmospheric trace gases, J. Geophys. Res., 97(D4), 3787-3804.

Ormeci, B., S. L. Sanin, and J. J. Pierce (1999), Laboratory study of NO flux from agricultural soil: Effect of soil moisture, $\mathrm{pH}$ and temperature, $J$. Geophys. Res., 104(D1), 1621-1629.

Otter, L. B., W. X. Yang, M. C. Scholes, and F. X. Meixner (1999), Nitric oxide emissions from a Southern African Savanna, J. Geophys. Res. 104(D15), 18,471-18,485

Pal, J.-S., et al. (2007), Regional climate modelling for the developing world: The ICTP RegCM3 and RegCNET, Bull. Am. Meteorol. Soc., 88(9), 1395-1402.

Papen, H., and K. Butterbach-Bahl (1999), A 3 year continuous record of nitrogen trace gas fluxes from untreated and limed soil of a N-saturated spruce and beech forest ecosystem in Germany: 1. $\mathrm{N}_{2} \mathrm{O}$ fluxes, J. Geophys. Res., 104(D15), 18,487-18,503.

Roelle, P. A., et al. (1999), Measurement of nitrogen oxide emissions from an agricultural soil with a dynamic chamber system, J. Geophys. Res., 104(D1), 1609-1619.

Roelle, P. A. (2001), Biogenic oxide emissions from cropland soils, Atmos. Environ., 35, 115-124.

Serça, D., R. Delmas, C. Jambert, and L. Labroue (1994), Emissions of nitrogen oxides from equatorial rain forest in central Africa: Origin and regulation of NO emissions from soils, Tellus, 46B, 243-254.

Simpson, D., et al. (1999), Inventorying emissions from nature in Europe, J. Geophys. Res., 104(D7), 8113-8152.

Skiba, U., K. J. Hargreaves, D. Fowler, and K. A. Smith (1992), Fluxes of nitric and nitrous oxides from agricultural soils in a cool temperate climate, Atmos. Environ., 26A, 2477-2488.

Skopp, J., M. D. Jawson, and J. W. Doran (1990), Steady state aerobic microbial activity as a function of soil water content, Soil Sci. Soc. Am. J., $54,1619-1625$.

Tulet, P., V. Crassier, F. Solmon, D. Guedalia, and R. Rosset (2003), Description of the MESOscale NonHydrostatic Chemistry model and application to a transboundary pollution episode between northern France and southern England, J. Geophys. Res., 108(D1), 4021, doi:10.1029/2000JD000301.

Van Cleemput, O., and L. Baert (1984), Nitrite: A key compound in N loss processes and acid conditions, Plant Soil, 76, 233-241.

Williams, E. J., A. Guenther, and F. C. Fehsenfeldi (1992), An inventory of nitric oxide emissions from soils in the United States, J. Geophys. Res., 97(D7), 7511-7519.

Yienger, J. J., and H. Levy II (1995), Empirical model of global soilbiogenic $\mathrm{NO}_{\mathrm{x}}$ emissions, J. Geophys. Res., 100(D6), 11,447-11,464.

N. Bruggemann and K. Butterbach-Bahl, Karlsruhe Research Center, Institute of Meteorology and Climate Research, Atmospheric Environmental Research, (IMK-IFU), Kreuzeckbahnstr. 19, 82467 Garmisch-Partenkirchen, Germany. (nicolas.bruggemann@imk.fzk.de; klaus.butterbach@imk.fzk.de)

C. Delon, R. Dupont, and D. Serça, Laboratoire d'Aérologie, Centre National de Recherche Scientifique/Université Paul Sabatier, 14 Avenue Edouard Belin, 31400 Toulouse, France. (delc@aero.obs-mip.fr; dupr@aero. obs-mip.fr; serd@aero.obs-mip.fr) 